\title{
Para além da teoria dos atos de fala: contexto e ideologia em charges no ensino de português para estrangeiros
}

Monografia apresentada ao Programa de Pós-graduação da PUC-Rio como requisito parcial para aprovação no curso de Formação de Professores de Português para Estrangeiros

Orientadora: Dr. Adriana albuquerque

Rio de Janeiro

Novembro de 2015 

PARA ALÉM DA TEORIA DOS ATOS DE FALA: CONTEXTO E IDEOLOGIA EM CHARGES NO ENSINO DE PORTUGUÊS PARA ESTRANGEIROS

BEYOND THE THEORY OF SPEECH ACTS: CONTEXT AND IDEOLOGY IN CHARGES IN THE TEACHING OF PORTUGUESE FOR FOREIGNERS

TAÍSSA RUAS DE MEIRELLES BENITES

Faculdade de Letras da PUC Orientadora: Dr. Adriana Albuquerque 


\section{Pontificia Universidade Católica $_{\text {ato }}$ DO RIO DE JANEIRO}

\section{Agradecimentos}

Agradeço a todos os alunos que me ajudaram a concluir a minha monografia de final de curso dando suas interpretações sobre as charges que foram usadas nos questionários. Agradeço também a toda minha família que sempre me apoiou, emocional e financeiramente. 


\section{Sumário}

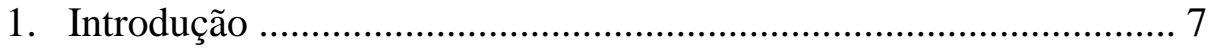

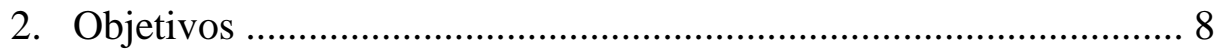

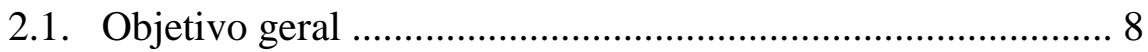

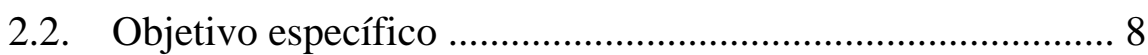

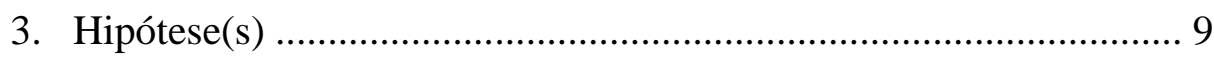

4. Revisão da literatura .................................................................. 10

5. Fundamentação teórica .............................................................. 12

6. Pressupostos metodológicos .................................................... 15

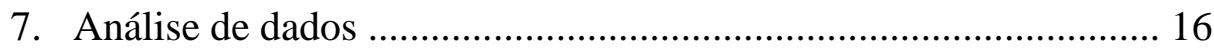

7.1. informante 1 PUC-Rio........................................................... 16

7.2. informante 2 PUC-Rio....................................................... 18

7.3. informante 3 PUC-Rio......................................................... 20

7.4. informante 4 PUC-Rio........................................................ 22

7.5. informante 5 PUC-Rio........................................................ 25

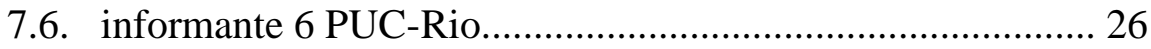

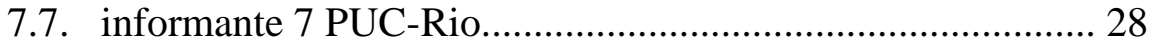

7.8. informante 8 PUC-Rio.......................................................... 30

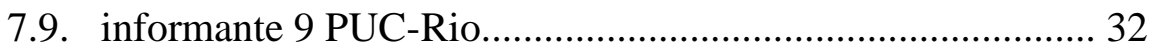

7.10. informante 10 PUC-Rio...................................................... 33

7.11. informante 11 PUC-Rio..................................................... 36

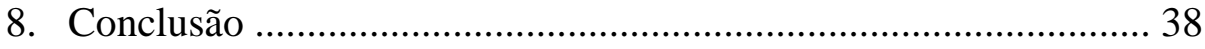

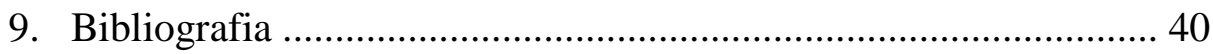

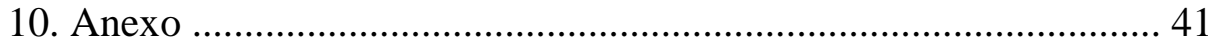




\section{Abstract}

The present study aims at analyzing a set of interpretations of cartoons made by PL2-E students and, through the cited qualitative survey, analyze in what way the notions of ideology and context influence student's interpretation. The interpretations, according to Austins' speech act theory, are perlocutionary acts.

As a way to expand and make the analysis of the interpretations made by students throughout the qualitative survey more reliable, the notion of context (Koch, 2002) and ideology (Dijk, 1998) are going to be correlated. These notions will be used as the mainstream/guide to the reflection on how and in what way PL2-E teaching methodology could be improved.

\section{Keywords}

teaching, context, ideology, speech act theory, PL2-E

\section{Resumo}

O presente estudo visa analisar um conjunto de interpretações de charges feitas por estudantes de PL2-E e, através da citada pesquisa qualitativa, avaliar a forma que as noções de ideologia e contexto influenciam na interpretação dos estudantes. As interpretações, de acordo com a teoria de atos de fala do autor John Austin, são atos perlocucionários.

Como uma forma de expandir e tornar a análise das interpretações feitas pelos estudantes durante a pesquisa qualitativa mais confiável, a noção de contexto (Koch, 2002) e ideologia (Dijk, 1988) serão correlacionadas. Essas noções serão usadas como embasamento teórico/ guia na reflexão de como e em que medida a metodologia no ensino de PL2-E pode ser melhorada .

\section{Palavras Chave}

ensino, contexto, ideologia, teoria dos atos de fala, PL2-E 


\section{Introdução}

(...) é sempre necessário que as circunstâncias em que as palavras forem proferidas sejam, de algum modo, apropriadas; frequentemente é necessário que o próprio falante, ou outras pessoas, também realize determinadas ações de certo tipo, quer sejam ações "físicas" ou "mentais", ou mesmo o proferimento de algumas palavras adicionais. (John Austin, Quando dizer é fazer)

O presente trabalho visa a analisar algumas interpretações de charges feitas por alunos de PL2-E e, a partir desta análise, avaliar de que forma as noções de contexto e de ideologia influenciam nessas interpretações. As interpretações analisadas, segundo a teoria dos atos de fala, tratam-se de atos de fala perlocucionários. Como ponto de partida para a análise das questões que serão abordadas neste trabalho, é de grande importância que desmembremos a citação de Austin reproduzida acima - uma parte da teoria dos atos de fala correlacionando-a tanto com a noção de contexto abrangida por Koch (2002) quanto a de ideologia abordada por Dijk (1998); noções essas que serão alvo de reflexão e de intercorrelação no decorrer do projeto a partir do prisma da área de ensino de português como segunda língua e como língua estrangeira. 


\section{Objetivos}

\subsection{Objetivo geral}

Neste trabalho objetivamos, em âmbito geral, estudar formas de aguçar o pensamento crítico de alunos de português como língua estrangeira a partir de uma abordagem discursiva, ideológica e cultural de ensino.

A ampliação e aplicação do presente projeto justificam-se à medida que o ensino de português como língua estrangeira carece de material acadêmico e didático para seu aperfeiçoamento. Carece, ainda mais, de material acadêmico que leve, ideologicamente, em consideração a língua em uso e seus efeitos no ensino e aprendizagem; ensino e aprendizagem estes sendo feitos através do uso de um material tão rico e complexo como a charge.

\subsection{Objetivo específico}

De forma mais específica, o presente estudo tem como propósito pesquisar meios que levem o aluno em questão a refletir o uso do gênero textual charge para além de uma noção estruturalista ou sócio-cognitiva. Objetiva-se estudar esse gênero testual como sendo moldado por fatores ideológicos e almejando propósitos específicos. Desenvolvendo essa reflexão crítica no aluno de PL2-E pretende-se que sua interpretação nesse gênero textual específico refine-se.

Para alcançar tal objetivo, serão usadas charges do autor Quino que tenham como foco principal alguma crítica social ou crítica a algum tipo de preconceito. 


\section{Hipótese(s)}

O presente projeto tem como hipótese que fatores culturais, a bagagem sóciocognitiva anteriormente adquirida pelo aluno estrangeiro e o contexto em que esse aluno encontra-se inserido, ou já tivera contato anteriormente, interferem no ato de fala perlocucionário desse aluno.

$\mathrm{O}$ ato de fala perlocucionário, em uma interpretação textual, por estar inserido em um determinado contexto e, por ser modificado e se modificar por influencia do sistema ideológico em que o aluno está inserido, tem potencial de ser alvo de destaque no ensino de português como língua estrangeira. 


\section{Revisão da literatura}

Nesta parte do estudo tenta-se fazer um breve levantamento de alguns trabalhos que já foram feitos sobre o ensino de português a partir do uso do gênero textual charge tanto em PL2-E quanto em L1. O primeiro trabalho apresentado tem como título "O gênero multimodal charge e sua articulação com o ensino de língua portuguesa: proposições didáticas.”.

Resumidamente, o texto apresenta a teoria sistêmico-funcional proposta por Hasan (1989) como forma de instrumentalizar os professores de língua portuguesa para o trabalho com os gêneros multimodais em sala de aula. Os autores apresentam, a partir de Simões (2010), a configuração do gênero charge e como o mesmo pode ser trabalhado em aulas de língua materna. Segundo os autores do artigo, ao apresentarmos ao aluno a Estrutura Potencial do Gênero (EPG), indicamos ao professor os estágios obrigatórios, quando se trabalhar com charge em sala de PL2E e como instrumentalizar esse gênero no ensino de língua materna. A proposição didática apresentada pelos autores consiste na apresentação de conceitos-chave da teoria de gêneros para os alunos; na pesquisa orientada sobre o gênero, por meio de um roteiro de perguntas direcionadas; na exposição simplificada da Estrutura Potencial do Gênero (EPG); e na resolução de exercícios que fixem o entendimento dos estágios obrigatórios para o ensino com o gênero.

O segundo texto apresentado nesta etapa é "Leitura de charges: da decodificação à compreensão". Nesse artigo, a autora Diana Xavier de oliveira discorre sobre a importância da leitura e do uso do gênero textual charge em sala de português L1 e como esse gênero auxilia na inclusão do aluno nas relações sociais, possibilitando que esse aluno perceba-se como sujeito crítico e cidadão.

Diana destaca que esse gênero textual também é importante didaticamente por nele serem utilizadas duas formas de transmissão de significado: a imagem e o texto. Esse gênero multimodal e intertextual, portanto, torna-se extremamente atrativo para alguns alunos à medida que sintetiza um número grande de informações em um pequeno espaço. Para a análise, foram utilizadas charges sobre educação, política e transporte público, que, segundo a autora, são assuntos relevantes a todos os cidadãos.

O terceiro e último texto apresentado na etapa do presente trabalho chama- 
se "Gênero charge: Construção de significados a partir de uma perspectiva interdisciplinar e dinâmica", dos autores Jorge Bidarra e Leidiani da Silva Reis. Os autores desse último trabalho discutem e analisam o processo interpretativo do gênero charge, levando em consideração o seu papel no contexto ensinoaprendizagem. Para tanto, a discussão é pautada na abordagem sociointeracionista de linguagem; essa abordagem presupõem que o texto deve ser visto como uma atividade interacional, criativa e social. Partindo-se desse ponto de vista, a interpretação de todo e qualquer texto torna-se uma tarefa complexa e que requer estratégias cognitivas e metacognitivas por parte de quem está realizando a ação. Como exemplo, Bidarra e Reis utilizam a Charge "Eleição para Papa" de autoria de Alberto Benett (2013). Ao longo do texto, os autores mostram que, no caso de charges, um dos requisitos fundamentais é o estabelecimento da intertextualidade, mormente com o envolvimento de outros textos jornalísticos. Ainda é observado que, em tal circunstância, sem o devido acionamento de conhecimentos prévios (conhecimentos de mundo e linguístico, por exemplo), a interpretação realizada pelo leitor tende a falhar.

Por tratar-se de um gênero composto pela mistura da linguagem verbal e não verbal (pictórica), a charge tem sido considerada um material muito rico para ser trabalhado com alunos em salas de aula. A interpretação desse gênero textual requer, muitas vezes, conhecimentos que envolvem não só política e religião, mas também fatos históricos, geográficos, artísticos e linguísticos.

A partir disso, os autores concluem que o caráter humorístico, informativo e opinativo das charges, bem como a ampla circulação social que assumem, fazem da charge um instrumento importante para a formação de alunos críticos e reflexivos, atributos cada vez mais solicitados pela sociedade. 


\section{Fundamentação teórica}

Esta parte do trabalho correlaciona a teoria dos atos de fala desenvolvida por Austin (1990) tanto com a noção de contexto abrangida por Koch (2002) quanto com a de ideologia abordada por Dijk (1998).

Um dos pontos abordados por Austin em relação à teoria dos atos de fala é o de que em uma enunciação temos três atos: Ato locucionário, ato ilocucionário, e ato perlocucionário. $\mathrm{O}$ primeiro ato diz respeito a própria estrutura linguística usada pelos locutores no momento da enunciação. O segundo ato, por sua vez, foca-se na intenção do locutor da enunciação ao produzir o ato locucionário; focase no processo cognitivo em si ocorrido do ponto de vista deste personagem, uma vez que tanto ele quanto seu interlocutor utilizam-se de estruturas específicas para transmitir pensamentos específicos. $\mathrm{O}$ ato que se destina à análise da criação de sentido tendo em foco esse interlocutor chama-se ato perlocucionário. Nele a análise recai, portanto, sobre a forma como o ouvinte/interlocutor da interação reage cognitivamente ao ato locucionário proferido pelo locutor/falante, podendo essa reação ser algo físico ou outro ato verbal. Por ser menos explorado, o presente trabalho focará no ato perlocucionário, e, especificamente, em como os sistemas ideológicos e o contexto afetam o processo cognitivo e sua reação durante este ato de fala.

Partindo da premissa de que os atos de fala possuem relação intrínseca com o contexto no qual encontram-se inseridos, é de suma importância que delimitemos a concepção de contexto a ser usada antes de darmos continuidade à análise. Para definir o que é contexto, Kock (2002) lança mão da concepção defendida pela linguística textual atualmente. Segundo essa linha de estudo

O contexto (...) abrange (..) não só o co-texto, como a situação de interação imediata, a situação mediata (entorno sociopolítico-cultural) e também o contexto cognitivo dos interlocutores que, na verdade, subsume os demais. Ele engloba todos os tipos de conhecimentos arquivados na memória dos actantes sociais, que necessitam ser mobilizados por ocasião do intercâmbio verbal (...). (KOCH, 2002: p.24)

Essa visão mais holística de contexto chama atenção para o fato de que ele é 
moldado e se molda a partir de processos cognitivos e sociopolítico-culturais. Cada sujeito traz em si uma bagagem já formada e que varia de indivíduo para indivíduo dependendo principalmente dos seguintes elementos: cultural, social, enciclopédico, linguístico, entre outros presentes na memória dos actantes da interação. Todos esses elementos atuam conjuntamente e são mobilizados durante a produção textual para que o enunciado seja inteligível entre os falantes.

Embora saiba-se que o processo cognitivo tem papel fundamental nessa criação de sentido, estudos acadêmicos não deixam claro de que forma e até que ponto a moldagem feita por esse processo sofre interferência de fatores ideológicos e como ambos contexto e ideologia podem afetar o ato de fala perlocucionário. Sobre a interação entre a teoria dos atos de fala e contexto, Austin (1990) declara que:

Quando examinamos o que se deve dizer e quando se deve fazê-lo, que palavras devemos usar em determinadas situações, não estamos examinado simplesmente palavras (ou seus significados ou seja lá o que isto for) mas sobretudo a realidade sobre a qual falamos ao usar estas palavras - usamos uma consciência mais aguçada das palavras para aguçar nossa percepção (...) dos fenômenos. (AUSTIN, 1990: p.10)

Entendendo a realidade citada por Austin como sendo delimitada e, em parte, determinada por fatores preexistentes em um sistema ideológico, essa "consciência" no momento da seleção vocabular feita durante a emissão de enunciados não se torna algo nem simples nem imparcial; a criação de sentidos durante o ato perlocucionário, por exemplo, tem intenção e propósito específicos durante o discurso. Muitas vezes a interpretação de um ato locucionário sofre interferência de nossos próprios interesses pessoais e/ou está baseada, inconscientemente, em discursos ideológicos moldados social, política e culturalmente. Sobre a relação entre discurso e ideologia Dijk esclarece que

O discurso permite que os atores sociais formulem conclusões gerais baseadas em várias experiências e observações. Por essas conclusões é permitido descrever eventos passados e futuros, descrever e prescrever, e tem a possibilidade de descrever ações e crenças em qualquer nível de generalidade ou especificidade. E para nós, curiosamente, o discurso não só exibe ideologias indiretamente, como outras práticas sociais podem fazer também, mas também formula explicitamente 
crenças ideológicas diretamente. (DIJK, 1998: p.193. minha tradução)

O discurso para Dijk, portanto, reproduz crenças ideológicas explicitamente. Contudo, como o autor citado também observa, outras práticas sociais não reproduzem esse sistema ideológico de forma tão clara e explícita, o que não impede que elas tenham uma repercussão guiada no momento em que formulamos pensamentos (atos perlocucionários). Para esse autor o status quo, guiado por grupos sociais específicos, muitas vezes está em nosso inconsciente.

Pretende-se aplicar essas asserções estudando a forma pela qual essa ideologia guiada influencia no processo de interpretação/produção textual, ato perlocucíonário, de alunos de PL2-E. O ato locucionário em questão serão charges da Mafalda de Quino voltadas para a reflexão crítica de preconceitos ou questões sociais. 


\section{Pressupostos Metodológicos}

A Metodologia a ser utilizada no presente trabalho é de base qualitativa e baseia-se na seleção de oito charges retiradas da internet sobre Mafalda, personagem criada pelo autor Quino.

Para a análise dessas charges serão escolhidos onze alunos de nível intermediário, a maioria de nacionalidades diferentes, em uma turma de PL2-E da CCI PUC-rio. A coleta de dados será realisada através do questionário presente no anexo 1 do presente projeto. O objetivo da coleta ter sido realisada de forma escrita visa o aluno ter mais tempo para refletir sobre o que está sendo pedido. A partir do estudo dessa produção textual dos alunos, que estará em itálico, pretende-se identificar, comparativamente, possíveis fatores que tenham levado aquele aluno a interpretar certa charge de um modo e não de outro, modo outro este escolhido por um falante nativo de português. 


\section{Análise de dados}

Foram selecionadas oito charges e, posteriormente, pedido para que alunos de PL2-E de nível intermediário/avançado com idade entre 18 e 22 anos analisassem, cada um, duas delas. O comando utilizado pra a análise foi: Analise as seguintes charges e, depois, diga se as situações apresentadas aconteceriam em seu país/cultura ou não.

Esta parte do trabalho avaliará de que forma fatores ideológicos, contextuais e culturais levaram os estudantes a identificar ou não a existência de algum tipo de preconceito ou alguma crítica social nas charges em questão. Caso o estudante tenha identificado o preconceito/crítica social presente na charge, será analisada a forma como o mesmo entende a questão e se esse entendimento influenciaria ou não no aprendizado da língua portuguesa. É importante informar que os nomes dos alunos são fictícios. Segue a primeira análise:

\section{a. Informante 1 - PUC- Rio}

Nome: Synd

Nacionalidade: Americana Data:18/10/15

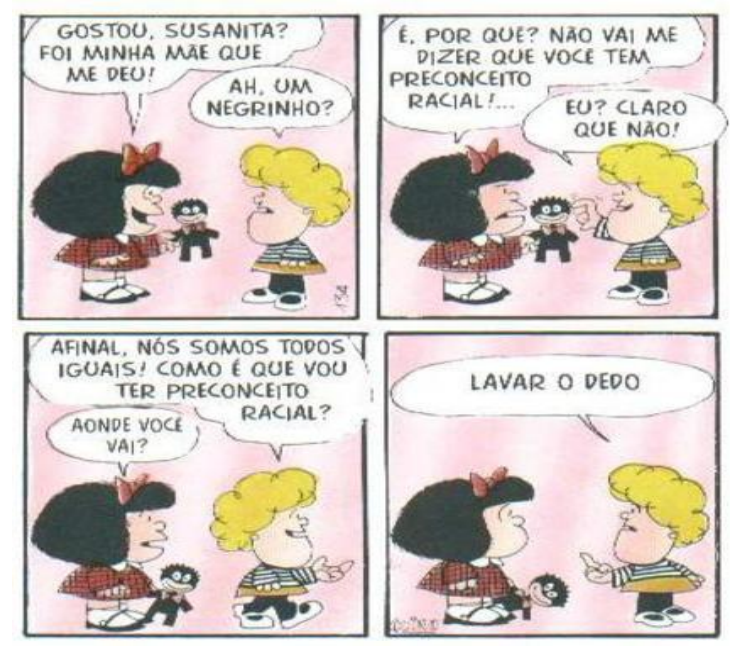

Nessa primeira charge, as figuras estão falando sobre preconceitos raciais. Aparece que a menina loira tem algumas preconceitos sobre a boneca negra. Depois de tocar o brinquedo, a menina loira insistiu que ela precisa lavar a mão dela. Mas ela também insistiu que ela não tem preconceitos. Eu acho que 
situações como isso aconteçam nos Estados Unidos também. Ainda existem divisões entre pessoas de raças diferentes e conflitos sobre raça. Ninguém quer admitir que ele tem pensamentos de racismo mas ainda algumas pessoas têm ações que pode refletir sentimentos de descriminação ou prejudica. Infelizmente ainda está comum de ver ou ouvir comentários maus sobre raça em nosso sociedade. Por exemplo, há pessoas que acham que se têm amigos negras,eles não podem ter preconceitos raciais. Isso não é verdadeiro. Ainda se você tem intenções boas, poderia falar coisas que refletir preconceitos raciais. Nos EUA, nós definimos essa tipo de ação como um "microaggression".

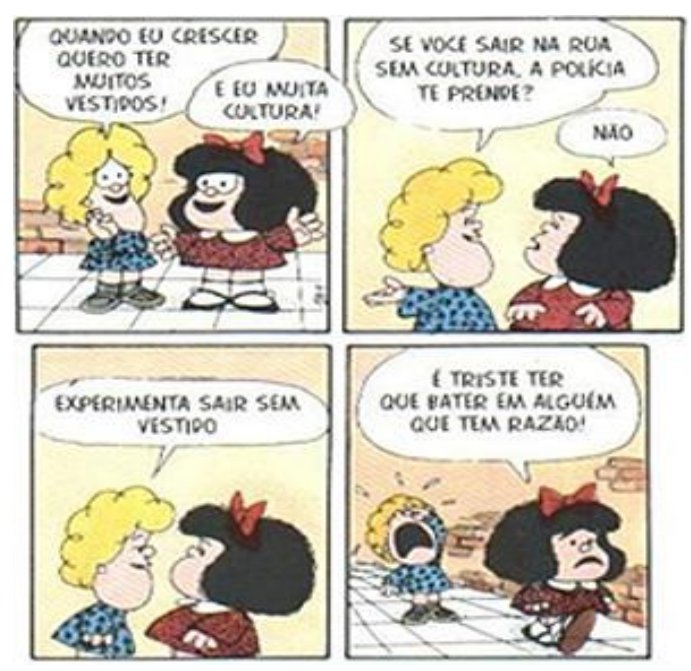

Neste charge as meninas estão discutindo desejos para o futuro. Enquanto uma das meninas desejou para muitas vestidos, a outra menina só quer ter experiências culturais. Mas no final, a menina loira convenceu a amiga dela que ela não tem liberdade de desejar para qualquer coisa. Ela disse que ela poderia ter uma falta de cultura, mas não pode faltar roupa ou a policia vai lo repreendê. Essa charge pode ser um comentário sobre estereótipos sobre o que mulheres deveria querer. Os expectativas do sociedade para mulheres têm um tendencia de ser limitado de só coisas matérias como vestidas em vez de coisas mais profundo como conhecimento cultural. Eu acho que minha cultura nos EUA também tem problemas com sexismo e preconceitos sobre o papel das mulheres no sociedade. Embora nós já tenhamos avançado um pouco com igualidade entre mulheres $e$ homens, há divisões ainda. Eu acho que agora é mais fácil para mulheres de decidir seus futuros, mas os esteriótipos tradicionais ainda influenciar as 
expectativas para mulheres em nosso sociedade.

Em ambos os contextos apresentados nas charges a aluna conseguiu identificar que existia algum tipo de preconceito ou crítica social. Na primeira charge ela compreendeu que ali estava representado um preconceito racial, e foi contra o mesmo. Segundo o conceito de contexto abordado por Kock (2002) a idade da aluna, assim como sua própria vivencia nos estados unidos influenciaram seu posicionamento crítico diante do preconceito apresentado, uma vez que a mesma teve a oportunidade de vivenciar situações em que esse tipo de preconceito aconteceu. Pelo o que a aluna descreveu sobre sua cultura em relação a esse tipo de preconceito, percebe-se que esse tópico é apresentado em seu país como sendo um impasse social. Esse impasse fez com que um novo verbete fosse criado para esse tipo de atitude: "microaggression". $\mathrm{O}$ fato de ela ter ido contra o preconceito abordado mostra que esse tópico seria tranquilamente abordado em aula e que a aluna teria conhecimento contextual suficiente para desenvolver um trabalho escrito, por exemplo.

Voltando-se para o conceito de ideologia levantado por Dijk (1998) o posicionamento da aluna em relação ao tópico racismo também foi determinado pelo fato de que aqui no Brasil esse posicionamento ideológico é bem aceito pela maioria da população, principalmente no meio acadêmico, que foi o meio para o qual a aluna sabia que estava escrevendo e que seria avaliada.

$\mathrm{Na}$ segunda charge, como foi dito, a aluna visualiza que existe alguma crítica social, porém entende essa crítica como sendo algo majoritariamente relacionado ao gênero sexual. Embora mostre que não está certa se a crítica social é sobre gênero - "Essa charge pode ser um comentário sobre estereótipos sobre o que mulheres deveria querer." - ela não é a favor da situação apresentada. Esse posicionamento ideológico apresentado pela aluna mostra que discriminação sexual seria um tópico que ela teria algum conhecimento para compartilhar também, e que isso não seria um tabu. Contudo, essa posição demonstra também que na cultura dela não é tão discutida a questão do "valor intelectual" X "valor material", uma vez que é essa a crítica presente na charge.

\section{b. Informante 2 - PUC- Rio}


Nome: Aldamir Arriola

Nacionalidade: Mexicano Data: /10/2015
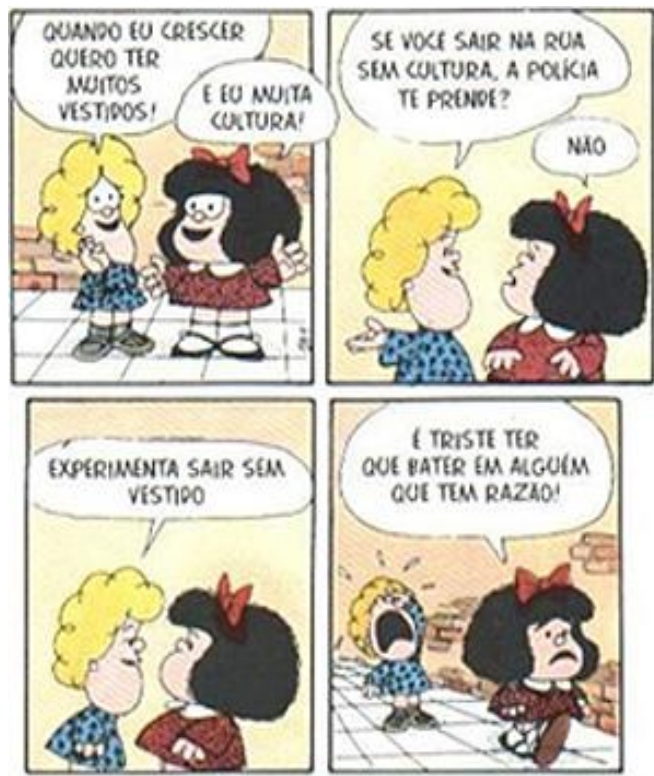

( TRISTE TER

OUE BATER EM ALGUIM QUE TUM RAZHO
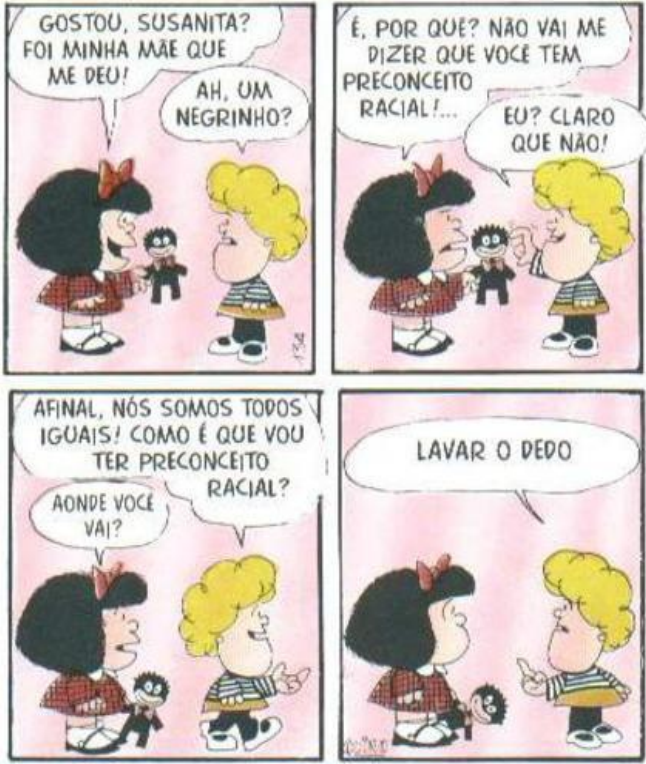

Eu nasci no México mas me mudei para os Estados Unidos a idade de oito anos. Entao, vou escrever sobre a cultura dos Estados Unidos. Acho que eu tenho algumas idéias negativas sobre a sociedade americana. Muita gente nos Estados Unidos acha que a gente pobre e sem casa ficam assim porque são preguiçosas. Pode ser que esto seja certo em algumas situações mas em minha opinião, a maioria ficam pobres porque moramos em uma sociedade que foi feito para certas pessoas. Se você da uma olhada, muita gente pobre é gente de cor (gente Latina, Negra, etc.). Por que acontece isso? Estados Unidos é um país muito bom 
mas tem gente com muitos preconceitos. Muita gente tem preconceitos sobre as pessoas de cor (Latinos, Negros). Esso causa que este tipo de gente tenha dificuldade para encontrar emprego, propensas a morrer mais cedo. Também é mais difícil para que os jovens de estas comunidades fossem a faculdade. Se esses jovens cometem algum crime, eles receberão mais anos na prisão que uma pessoa branca. Em conclusão, a situações apresentada aconteceria nos Estados Unidos, a gente lá tem muitos preconceitos que magoam a gente de cor.

O aluno, na maior parte do tempo, analisa criticamente a cultura na qual viveu a maior parte de sua vida. Ele ter vivido sua infância em um país latino e depois ter mudado-se para os Estados Unidos é um dos fatores contextuais (Kock, 2002) que fez com que conseguisse visualizar a existência do preconceito racial na primeira charge presente no questionário.

Contudo o aluno não especifica o que consegue interpretar do que está acontecendo na segunda charge; ele dá a entender que a segunda charge fala sobre preconceito de classe social. Essa falta de informação em relação à segunda charge é explicável levando em consideração fatores sociais tendo em vista que o tema preconceito racial está muito mais presente na sociedade norte americana - e principalmente no dia a dia do aluno, uma vez que o mesmo é de origem latina do que a crítica "cultura $\mathrm{x}$ bem material".

Essas informações revelam que, pelo menos com alunos que possuam essas características culturais, há a necessidade de uma explicação mais detalhada do contexto e dos aspectos sociais presentes na charge, caso o professor queira abordar o tópico "valorização do bem material em detrimento do cultural"; o professor deve explorar a intenção da personagem Mafalda, principalmente no último quadro quando a mesma dá razão à sua amiga.

\section{c. Informante 3 - PUC- Rio}

Nome: Francisca Inglesias

Nacionalidade: Argentina Data: 20 / 10/2015 

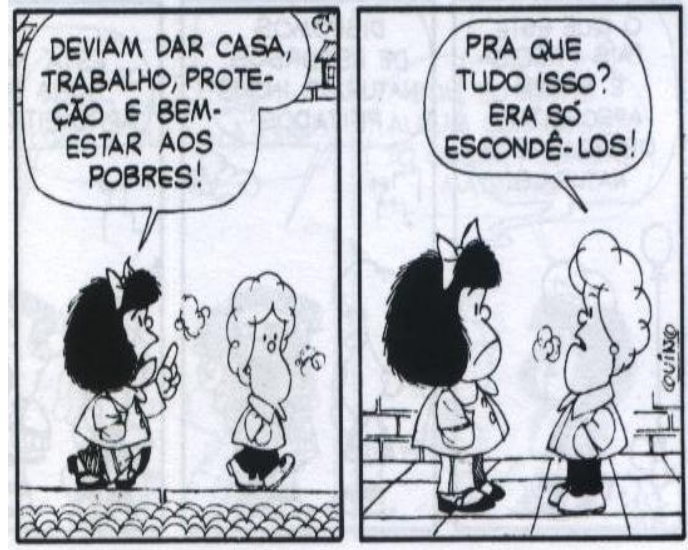

No meu país também acontece essa intolerância para os pobres. Acha-se que eles ficam nessa condição de pobreza só por eleição (o que só em alguns casos é verdade). Eles querem que o governo se ocupe de manter os pobres longe da cidade onde moram as classes meia e alta.

Aqui no Rio isso acontece de forma mais notória, onde as favelas foram pacificadas unicamente na zona sul, e alguns expulsados das favelas dessa zona para morar na zona norte. Na minha cultura eles não são verdadeiramente expulsados de suas vivendas, mas são marginados pelo governo que não melhora as condições de vida em os setores pobres, e pelo povo que reclama todas as "esmolas" que o governo da para eles.
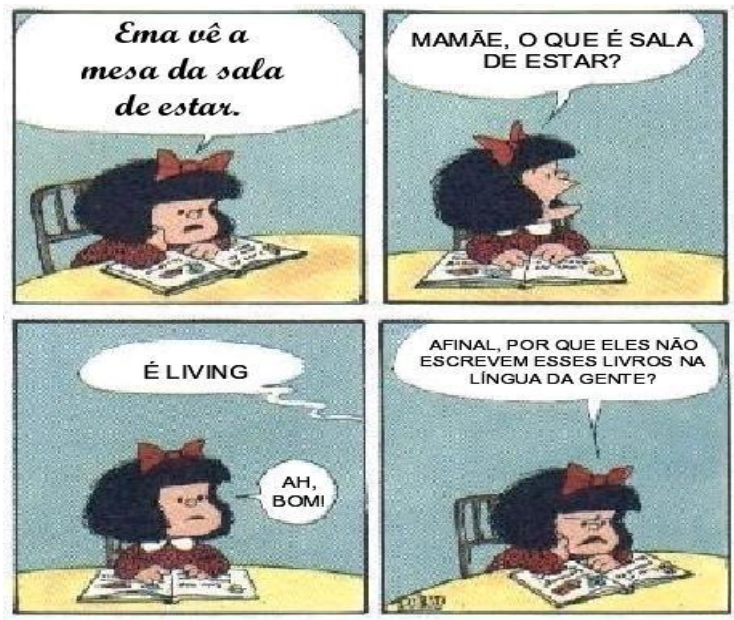

Em minha opinião, o mundo todo está se unificando, e é cada vez mais normal que expressões de outras línguas sejam tomadas como próprias. Até às vezes resulta mais pratico e confortável utilizar uma palavra em outra língua para definir alguma coisa que na própria língua seja mais complicado. 
No meu país, o estudo de outras línguas ainda não está muito desarrolhado. É com a minha geração que o cambio esta acontecendo, e situações como a que acontece com Mafalda vão sendo cada vez mais usuais.

Nota-se que a aluna conseguiu visualizar que existe algum tipo de impasse em ambas as charges, embora na segunda ela tenha deixado velado que a charge tratava de uma crítica social e que na cultura dela há também tanto a discriminação entre classes sociais quanto a questão da influência da língua estrangeira na cultura de origem. Segundo Kock (2002) e Dijk (1998) a interpretação dada à charge pela aluna tem base tanto no fato da mesma ter vivido e está em país latino americano quanto no fato de ser jovem, como a própria aluna explicita em sua interpretação. Outro fator que influenciou na interpretação das duas charges foi o contexto sócio-cultural grau de instrução da aluna. É notório também que o contexto enciclopédico é um forte influenciador, principalmente na segunda interpretação, pois somente tendo sofrido influência da globalização a aluna teria em sua schemata ferramentas para interpretar o ato locucionário da forma interpretada.

\section{d. Informante 4 - PUC- Rio}

Nome: Chistine Cronier

Nacionalidade: Americana Data: 9/10/15
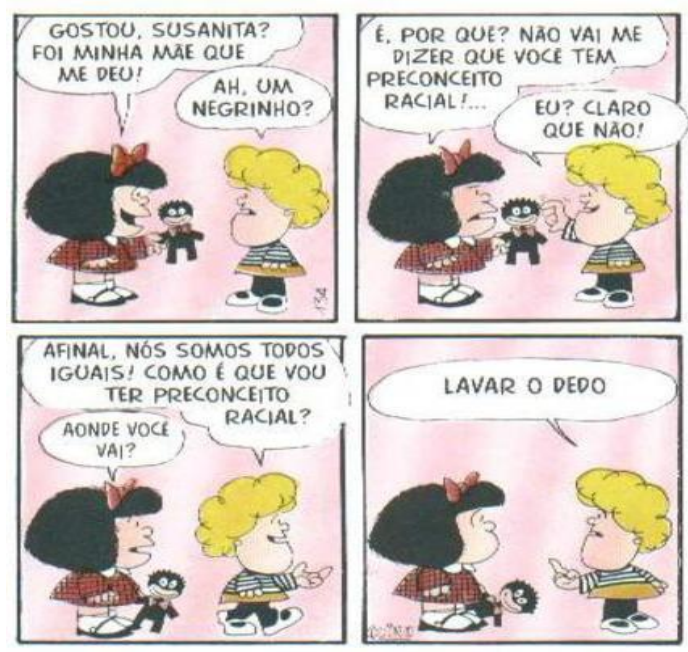
Algumas pessoas anuncia com certeza que não são racistas mais ao mesmo tempo, mante sua distancia das pessoas que são diferentes ou nesse caso, coisas que são representações das pessoas que são diferentes. Isso acontece muito onde eu estudo nos Estados Unidos. Eu estudo no Universidade da Califórnia, Berkeley, uma Universidade que tem um reputação muito boa e muito liberal (o movimento de liberação do expressão nos Estados começou lá). Por causa dessa reputação, os alunos se consideram muito liberal e "acima" das problemas de racismo e preconceito. Mais ou mesmo Universidade recebeu reclamações dos alunos negros (e alunos de diferentes comunidades minores) que eles não se sentem aceitos. Então, que esta acontecendo? Eu acho que a reputação do Universidade e tipo atua tipo máscara que preveni as pessoas de sabendo o verdade. O verdade é que todas as pessoas têm seus próprios preconceitos e estereótipos. Ninguém é perfeito mas numa comunidade que vala muito de ser politicamente correto, a gente sente uma pressão de atuar como é liberais perfeitos. Quando a gente insiste que no tem essas preconceitos, está é parte do problema. A fim de que resolva essas problemas do racismo, classismo, sexismo, a gente precisa admitir seus próprios problemas.

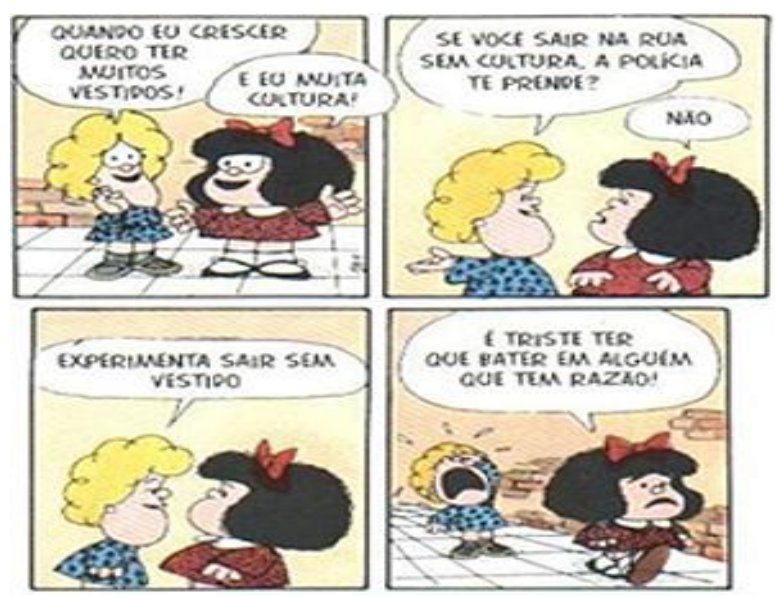

A segunda charge é sobre essa ideia que como a gente se veste e as coisas que tem no geral são mais importante do que cultura, ou pode ser um substituição para cultura. A loira, Susanita, representa consumismo, que é parte da cultura dominante. Mafalda representa a cultura, que inclui a importância da educação. Embora Mafalda quer acreditar que cultura é mais importante do que por exemplo a quantidade dos vestidos alguém tem, ela sabe que no sociedade dela, 
coisas materialistas são mais valorizado. Ironicamente, Mafalda bate Susanita, um ação que não e da muita 'cultura'. Ela admiti a final que Susanita foi correta.

Onde eu moro no Berkeley, California eu acho que tem muitas pessoas s ã o mais preocupados da cultura do que coisas materialistas. Atualmente, Berkeley tem um reputação na California porque as pessoas sao mais livres com seu roupa. As vezes pessoas sair sem roupa! Verdade! Eu acho que no ambiente do Universidade, educação e mais importante do que a aparência da pessoa. Mas, através da perspectiva geral, muitos pessoas são estudando no Universidade não porque eles querem aprender coisas, mais porque eles querem procurar um bom trabalho e ganhar dinheiro. E aquele dinheiro pode ser usado para ganhar coisas, como roupa, e consequentemente respeito e aceitação social. Para muitas pessoas, o objetivo ainda e para ter coisas materialistas. Então, o consumismo tem mais influencia é mais valioso, mesmo que pessoas não admitam.

Como foi observado, a aluna em questão interpretou criticamente as charges apresentadas levando em consideração aspectos culturais, sociais e raciais, colocando muitas vezes a própria faculdade em que estuda nos Estados Unidos em situação delicada, uma vez que no fim da segunda interpretação explicita que até nas faculdades "o consumismo tem mais influencia é mais valioso, mesmo que pessoas não admitam".

Pode-se perceber que o fato de a aluna ter conseguido perceber criticamente que existia alguma crítica social nas charges foi devido, segundo Dijk (1998), ao fato de que o meio social em que viveu despertou nela uma consciência crítica e liberal em relação aos tópicos abordados nas charges; essa consciência crítica foi criada, inclusive, durante sua estadia na faculdade de Berkeley.

Com esses dados é observado que alunos com essas características contextuais (Kock, 2002) - jovem, e que já entrou em contato com um ambiente acadêmico no qual o desenvolvimento de um pensamento crítico no aluno é uma questão a ser abordada e refinada - podem ser amplamente beneficiados com o uso do gênero textual charge, uma vez que uma das vertentes desse gênero é a abordagem crítica de preconceitos/impasses sociais.

Durante o uso em sala de aula da charge analisada o professor pode explorar o texto (imagem e texto escrito) intertextualmente com outros gêneros, a fim de tornar a aula mais rica. 


\section{e. Informante 5 - PUC- Rio}

Nome: Jucy Clare James

Nacionalidade: Americana Data: 18/10/15
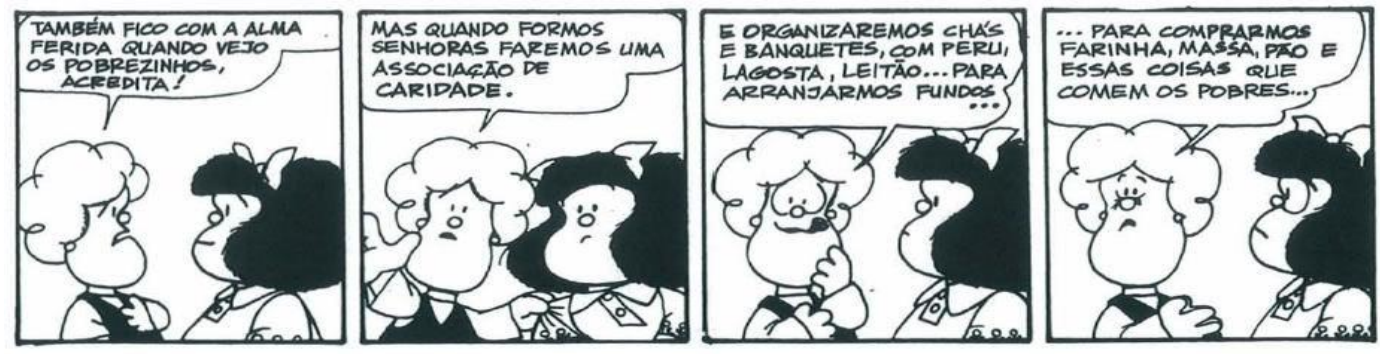

As situações apresentadas nas charges também aconteceriam em meu país, os Estados Unidos.

A primeira charge, sobre o pobreza, é muito similar nos Estados Unidos. Existe uma gigante população de pobreza, pessoas sem abrigo, só podem morando com seus famílias nas ruas das cidades. Assim como a charge, quando eu vi pobreza em meu próprio pais, eu queria ajudar e mudar o sistema. Eu queria oferecer comida e roupas e uma vida melhor. Mas nas charges, a mensagem é um pouco sobre gênero, porque o homem sugeriu que as senhoras formem um a associação de caridade.
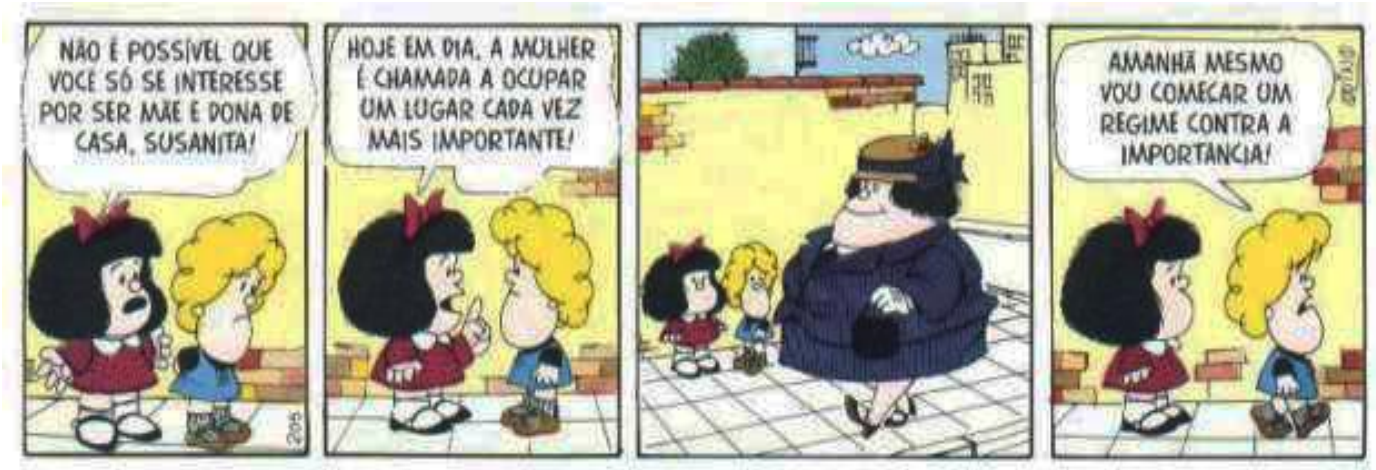

A segunda charge é também sobre papéis de gênero e a diferença em expectações entre as mulheres e os homens. O menino é confusa porque a 
menina não é interesse em coisas domesticas o ser "Mae de Casa." Quando a menina diz para ele sobre o papel de uma mulher é diferente hoje, porque elas são mais importantes, ele não gosta. Ele, e outros homens nos Estados Unidos também, não gostam mudanças e quer o status quo. Eu acho que os homens não se sentem necessários por mulheres com tanta frequência e estão preocupados que eles vão perder a sua importância.

Como verificado, em nenhuma das duas charges a aluna em questão visualizou corretamente que existia o tipo de preconceito ou crítica social apresentado. Um dos motivos é que o contexto situacional presente nas imagens das charges (Kock 2002) mostrou para a aluna que nelas existiam personagens do sexo feminino e masculino, o que não procede. Faltou à aluna o conhecimento contextual/cultural relacionado aos personagens do autor Aquino. Essa interpretação erronia em relação ao gênero sexual dos personagens apresentados nas charge é contextualmente explicável também pelo fato da aluna não ter nível de proficiência na língua portuguesa suficiente para interpretar as charges apresentadas.

Sua interpretação, embora crítica, foi quase que totalmente voltada para o papel do home e da mulher na sociedade americana nos dias atuais. Esse foco foi dado pelo contexto enciclopédico (Dijk 1998) que a aluna possui. Para ela a questão de gênero e algo em evidência.

\section{f. Informante 6 - PUC- Rio}

Nome: Adiley Ramis

Nacionalidade: Americana Data: 9/10/15 

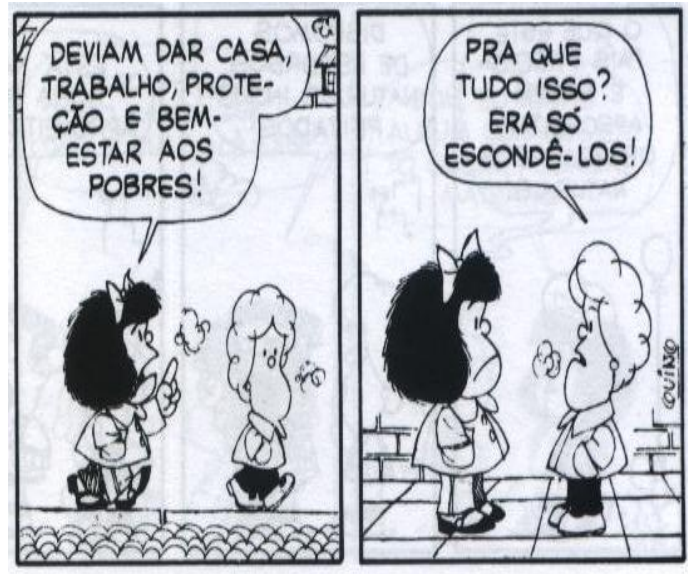

A primeria situação ocorre mais nas cidades grandes. Nos Estados Unidos o governo ajuda ativamente a população mais carente com programas de integração social que geram renda e ajudam as pessoas a eleverarem-se socialmente, ou seja, de maneira alguma são ignorados pela sociedade ou negligenciados pelo governo. Mas, a ajuda muitas vezes é limitada devido ao abuso de algumas pessoas sobre os benefícios oferecidos.
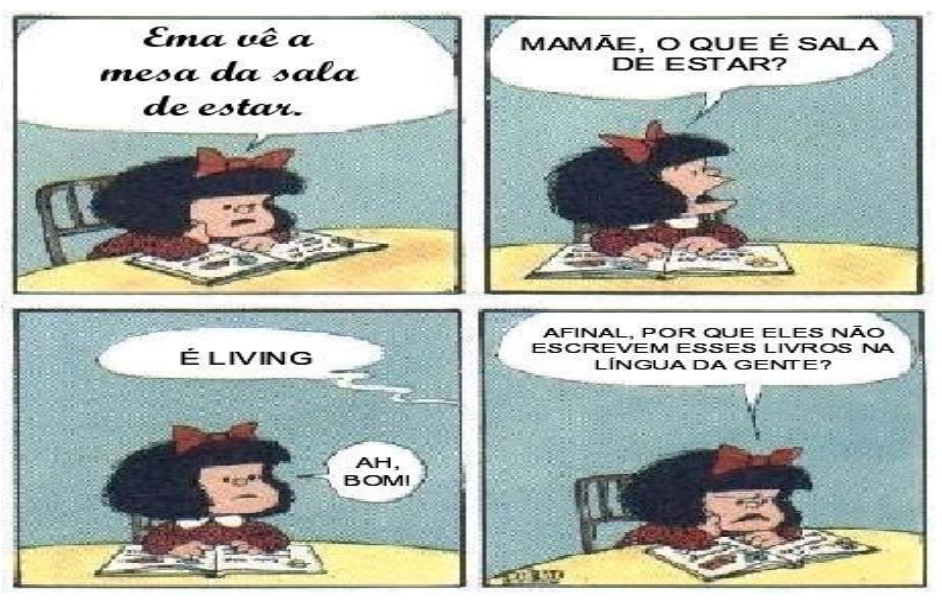

A segunda situação também não ocorre, apenas livros na língua inglesa são utilizados para meios didáticos. Livros em língua estrangeira somente são utilizados quando há interesse no aprendizado de cultura e língua de outro país. Mas, na população latina tem complicação porque as vezes não tem livros ou instruções na língua espanhola.

Como pode-se observar, em nenhuma das duas charges a aluna notou que existia algum tipo de preconceito ou questão social. Acredito que, embora a 
capacidade escrita da aluna seja razoável, sua capacidade de leitura acabou interferindo na interpretação da charge. A aluna em questão focou-se mais no como as situações apresentadas se comportariam no seu país do que na própria interpretação da charge. Esse posicionamento é explicável ideologicamente (Dijk, 1998) pelo fato de a cultura americana ser nacionalista.

Um outro fator contextual, além dos que já foram citados, causador de interferência durante a ato de fala perlocucionário foi o fato das ilustrações presentes nas charges expostas à aluna não darem muitas pistas do que está sendo discutido verbalmente, diferentemente de outros textos do mesmo gênero.

\section{g. Informante 7 - PUC- Rio}

Nome: Anny-Louize

Nacionalidade: Francesa: 20/10/15

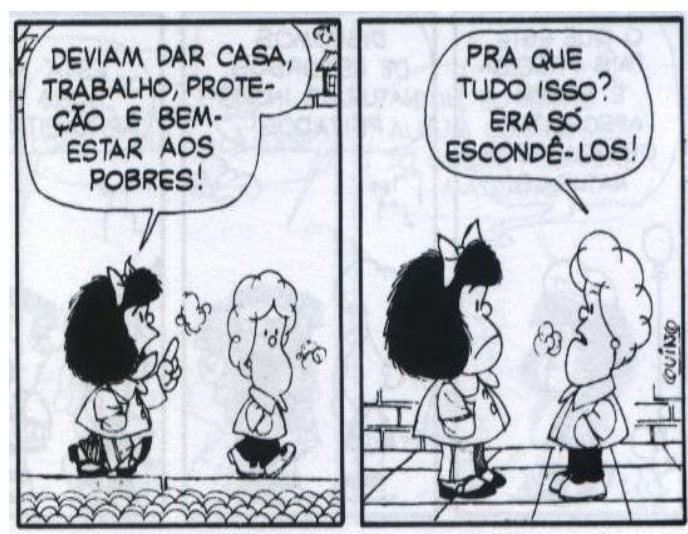

Na primeira charge, se pode ver uma discussão entre Mafalda e seu amigo sobre o papel do Estado com respeito o problema da pobreza. Para a menina, o Estado deve actuar a favor duma integração das populações mais pobres, fornecendo para eles uma casa e um trabalho. Mas o menino parece achar que esta solução não fundamentalmente eficaz, porque não resolvem os problemas dos pobres, mas só escondê-los.

Na França, acho que temos a mesma natureza de problemas: o governo socialista quer ajudar os mais pobres, dando-los casas e dinheiro para melhorar o quotidiano. Em realidade, as coisas não mudam profundamente porque o nível das escolas publicas não sobe, e a renda que vem do Estado não encoraje os pais 
a trabalhar para sair realmente da pobreza. Então, a solução do Estado esconde mais os pobres que ela lés ajudam.
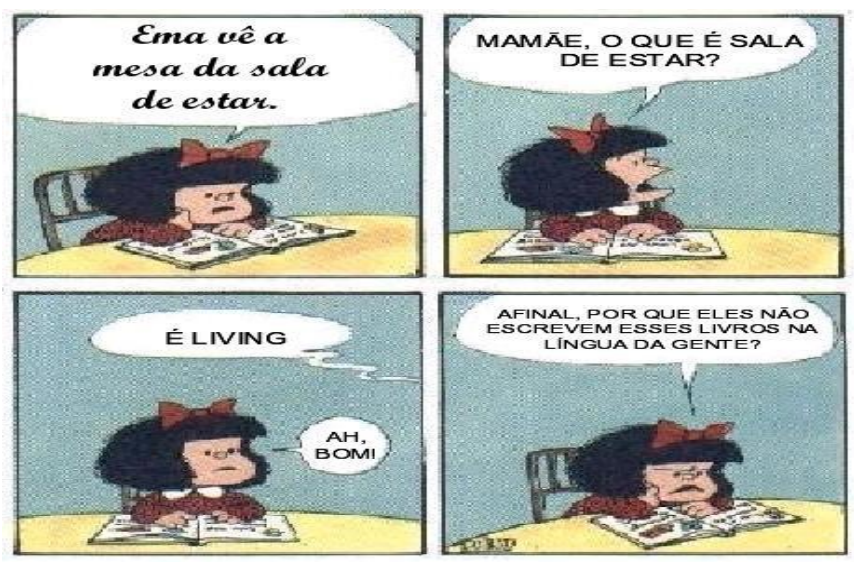

Na segunda charge, é engraçado ver que Mafalda entende melhor uma palavra em inglês que uma na sua própria língua. Na minha opinião, este poderia acontecer na França, porque o francês tem muitas palavras que vem de outras línguas, então se poderia explicar uma palavra em francês com outra em inglês. Mas As vexes este tipo de situação vai acontecer sempre mais a causa da globalização, e da influenza cada vez mais importante do inglês na lingua francesa.

Na interpretação da primeira charge a aluna visualiza que há um "problema" entre classes sociais explicitado na fala de Susanita, e, mesmo confundindo a personagem com um menino, não aparece em sua interpretação nenhuma questão de diferença de gênero. A aluna, contudo, não entende completamente a crítica social feita na charge pois explicita que a proposta de Susanita para o problema seria esconder os pobres. Na verdade Susanita dá a entender, pelo menos para um falante nativo de português no Brasil, (Kock 2002) que essa solução (esconder os pobres) é a solução mais fácil, por causa das palavras "tudo" e "só". Essa divergência é contextualmente explicável pela ainda baixa proficiência da aluna na leitura em português, mas mostra, contudo, um nível razoável na escrita.

Em relação à segunda charge, a aluna não conseguiu visualizar completamente a questão social abordada. A aluna não explicitou que o que estava em destaque na charge é o fato de a Mafalda preferir uma outra língua que não a nativa em um livro didático. A interpretação é amplamente guiada pelo conhecimento de mundo obtido pela aluna. Contudo, vemos que tanto na 
interpretação da charge um quanto na da charge dois da aluna há uma visão crítica de mundo e da sua própria cultura.

\section{h. Informante 8 - PUC- Rio}

Nome: Edwije Largiau

Nacionalidade: Francesa Data:20/10/15

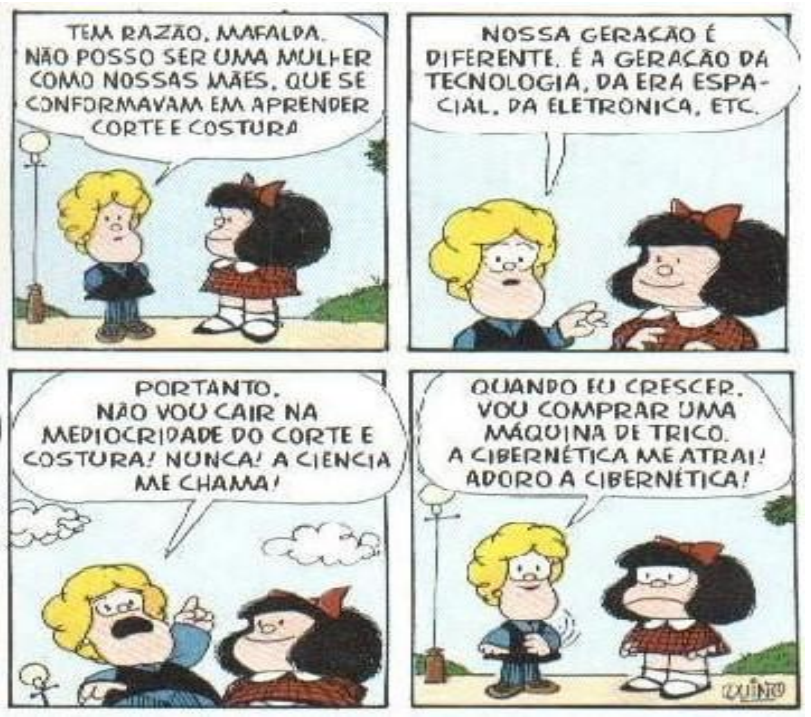

Nessa primeira charge, a amiga da Mafalda explica que ela vai viver com o seu tempo e usar as novas tecnologias, e não ser uma mulher de casa como as da geração dos seus pais. Mas depois ela diz que vai comprar uma maquina de tricô, pensando que isso também é uma coisa de alta tecnologia.

Isso não aconteceria na França porque acho que as pessoas já estão bem pegadas naquelas novas tecnologias. É muito raro ver pessoas da minha geração que ainda fazem coisas da geração dos nossos pais, como costura. 


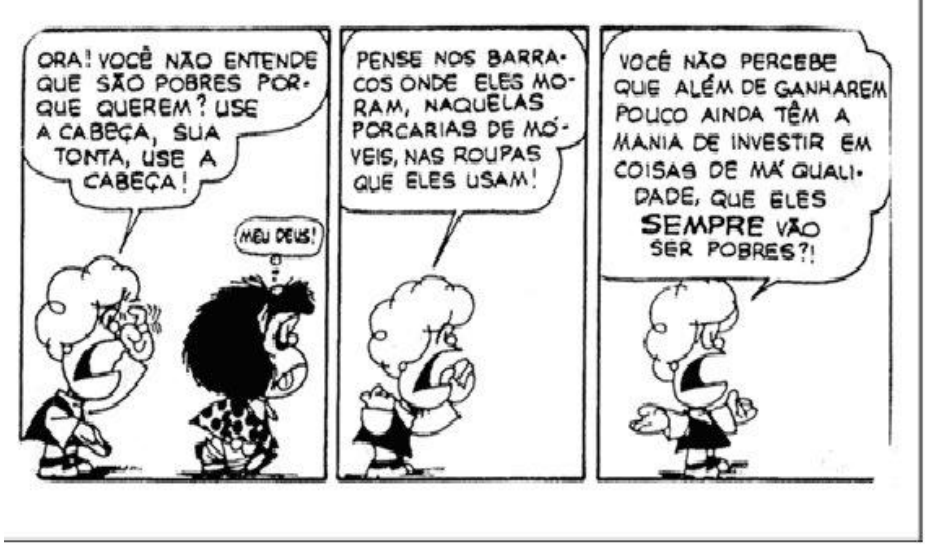

Nessa segunda charge, a amiga da Mafalda explica que os pobres sempre serão pobres porque querem ser assim.

Na França, seria possível ouvir coisas assim na rua, por exemplo, porque tem muitas pessoas que não acreditam que pessoas podem acabar vivendo na rua porque perderam tudo. Algumas pessoas acham que não é possível viver assim, que de uma maneira ou outra tem uma solução para não acabar assim. Então é por isso que pessoas pensam que os pobres querem ser pobres.

$\mathrm{Na}$ primeira charge a aluna consegue visualizar que existe uma crítica social: as pessoas pensam que estão inovando mas na verdade estão fazendo exatamente o que as pessoas anteriores a ela fizeram, só que se utilizando de outros meios. Essa interpretação foi possível, como a própria aluna explicita, porque em sua cultura natal o uso de novas tecnologias é comum. Embora "máquina de tricô" não seja uma tecnologia tão recente, segundo o conceito de contexto abordado por Kock (2002), se a aluna não tivesse conhecimento de mundo sobre essa tecnologia, não conseguiria entender a crítica feita pela charge.

Outro fator contextual correlacionado à noção de ideologia abrangida por Dijk (1998) chama a atenção na interpretação feita pela aluna francesa. Segundo essa aluna a idade é um fator que "seleciona" as pessoas que estão mais acostumadas com tecnologia das que não estão. Essa ideologia demonstra que a sociedade francesa é uma sociedade/cultura que aceita, até certo ponto, fatores de modernização e essa característica está presente no ato perlocucionário produzido pela aluna. 
$\mathrm{Na}$ interpretação da segunda charge observamos que a aluna também consegue visualizar a crítica social feita pela charge, embora critique de certa forma o fato de que em sua cultura algumas pessoas são coniventes com a situação descrita. Essa crítica, segundo Kock (2002) dá-se pelo fato da aluna ter entrado em contato, e ainda estar, com o meio acadêmico.

\section{i. Informante 9 - PUC- Rio}

Nome: Silvia Camila Medjia

Nacionalidade: Colombiana Data: 21/10/15
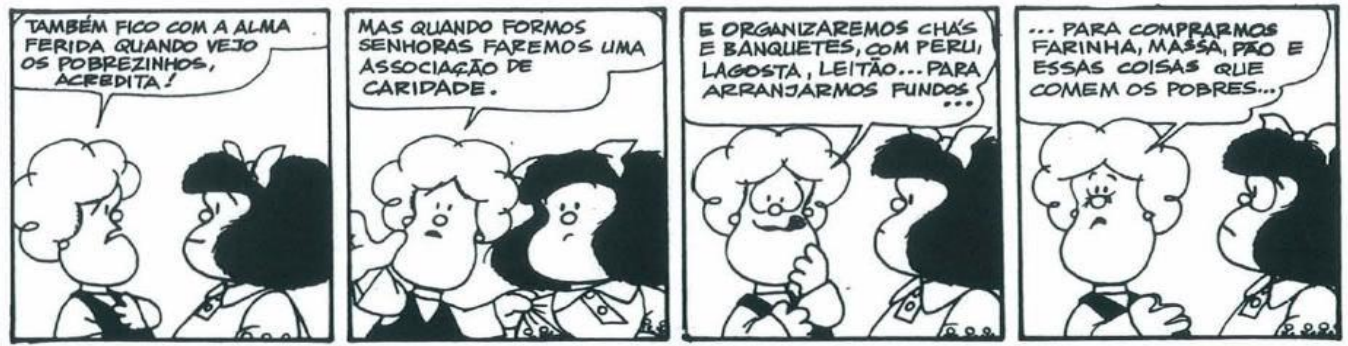

As duas situações são muito "comuns" no meu pais. Mesmo se as condições da mulher tenham melhorado, e se a pobreza melhoro, nos últimos anos, a Colômbia ainda é um pais cheio de desigualdades sociais e de gênero, que nem o Brasil e outros visinhos da america do sul.

A violência que existe na Colômbia atualmente, e a impotência que sente a população frente a esse fenomeno, faz que a forma com a qual se tenta lidar com a problemática da pobreza não tenha o efeto desejado. Hoje em dia muitos acreditam que ajudam, mais na verdade continuam a perpetrar a diferenciação entre ricos e pobres como mostra a primeira charge.
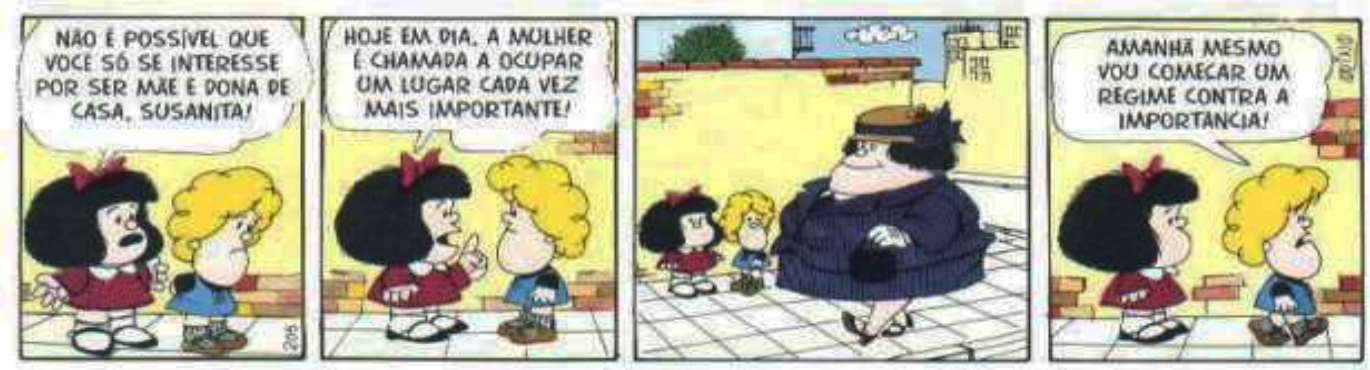

Igualmente, como o mostra o segundo charge, a condiçao da mulher, mesmo depois de tantos anos de luta parece não ter mudado. Cada dia se fala que as mulheres estão a ter uma maior importância nos diferentes círculos da 
sociedade, mais na verdade, as diferencias de gênero ainda são muito importantes. Ainda hoje, asistimos a um fenomeno de violência domestica muito alto, a uma discriminação sexual no sector profissional etc...

Como pode-se observar a aluna percebeu que existe alguma questão crítica em ambas as charges. Na primeira o contexto sócio-cultural (Kock, 2002) em que a aluna viveu a maior parte da vida permitiu que a mesma conseguisse visualizar que a crítica social feita na primeira charge é em relação à diferença de classe social. Além de conseguir visualizar o tipo de preconceito abordado pela charge a aluna o aborda de forma crítica e reflexiva - "Hoje em dia muitos acreditam que ajudam, mais na verdade continuam a perpetrar a diferenciação entre ricos e pobres".

$\mathrm{Na}$ interpretação da segunda charge, contudo, observa-se que a aluna aborda a questão do preconceito de gênero, o que no entanto não é a questão social levantada pela charge. Nessa charge um falante nativo de português observa que a questão é a descriminação de pessoas acima do peso. Essa divergência nas interpretações foram causadas, segundo Dijk (1998), pelo fato da questão do sobre peso não ser um fator ideológico muito relevante na cultura da aluna e nem em seu contexto enciclopédico, diferentemente da crítica social em relação à diferença de gêneros. Embora a aluna seja colombiana, e, portanto, faça parte da América do sul, ela não conseguiu visualizar o fator ideológico sobre peso, que é relevante na cultura brasileira. Portanto, verifica-se que o tipo de crítica social influenciou diretamente no ato perlocucionário da aluna em relação à segunda charge analisada.

\section{j. Informante 10 - PUC- Rio}

Nome: Clara Clubiak

Nacionalidade: Colombiana Data: 22/10/15 


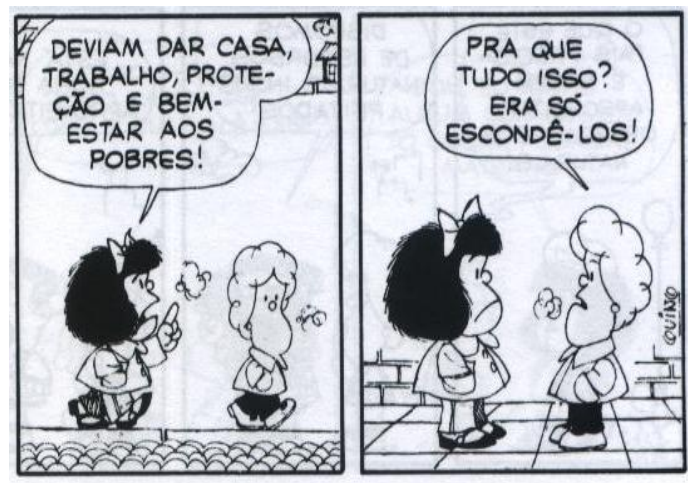

Na Dinamarca os pobres realmente estão tratado bem. Obviamente não e bom que ainda seguem sendo pobres, mas considerando isso acho que têm boas condições na Dinamarca. Na Dinamarca a gente paga muitos impostos (tipo 40$60 \%$ da renda dependendo do salario) para que todos os habitantes podem ter boas condições da vida. Então as pessoas pobres que aqui no Brasil são pessoas sem abrigo realmente tem casas onde se podem dormir quando faz frio durante o inverno. Essas casas são suportados pelo estado o pelas pessoas voluntarias. Também muitas vezes eles têm comida livre e muitas oportunidades para encontrar um trabalho. Ao final na Dinamarca temos um jeito de dizer que as pessoas sem abrigo escolhem ser assim, simplesmente porque têm tantas oportunidades de encontrar trabalho para suster suas vidas. E muito provável que não sempre seja assim, também porque muitas pessoas da rua estão lá porque têm um abuso das drogas que custa muito e que impede encontrar ou pelo menos manter um trabalho. Ademais que isso, seguramente os pobres têm mas oportunidades na Dinamarca do que em outros países. Por outro lado o que esta acontecendo agora com os imigrantes da Síria e do Médio Oriente demostra que Dinamarca não e um pais tão generoso como o mundo diz e como eu realmente quiser que e. Espero que Dinamarca com toda Europa aprende rápido que essa situação dos imigrantes não e sustentável e que se precisa tanta a cooperação como a generosidade para solucionar a problema e ajudar esses milhões de pessoas que faltam as coisas mas profundas para manter uma vida adequada.

Então a situação na charge não aconteceria na Dinamarca a menos que esses pobres fossem imigrantes da Síria. 

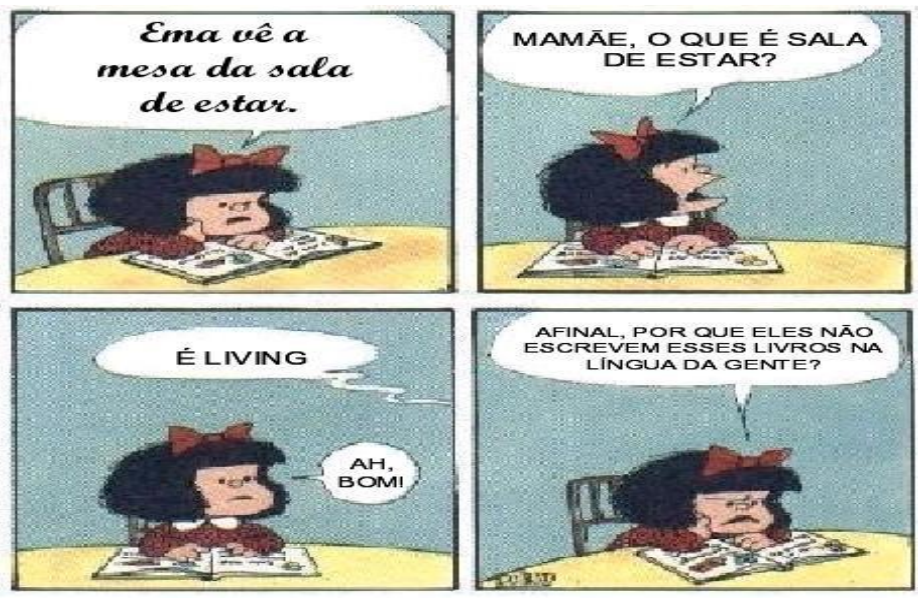

Acho que essa situação nem aconteceria na Dinamarca, porque realmente o idioma dinamarquês já é muito influído pelos outros idiomas. Como Dinamarca é um pais pequeno estamos acostumados a ajusta-nos em muitos aspetos e o idioma não é diferente. Os habitantes na Dinamarca viajam muito e também tem trabalhos onde é importante que se pode comunicar com todo o mundo, então e inevitável que em um momento o idioma vai ser afetado. Mais, como a identidade da Dinamarca sabe que o destino do pais depende de sua habilidade de navegar no mundo que já e muito global, porque um pais pequeno e dependente de suas relações internacionais para poder ter influencia e para poder sobreviver economicamente, não tem essa proteção nacionalista como o Brasil acho. Obviamente têm pessoas que querem proteger o idioma mas não e muito forte essa opinião. Ao final seria mas fácil sim todo o mundo tivesse um único idiomaassim a integração tão como a empatia da outras culturas não seriam tão difíceis. Talvez fosse um pouco mais chato também ;)

$\mathrm{Na}$ primeira charge a aluna identifica que há um preconceito presente na charge e que esse preconceito é em relação à classe social. Esse preconceito é analisado, na maior parte do tempo, do ponto de vista da cultura dinamarquesa, embora em alguns pontos a aluna faça um comparativo com a cultura brasileira. Verifica-se que a aluna não apresenta problemas em relação à questão abordada. A aluna diz, criticamente, que ainda há um pouco desse preconceito em sua cultura e que isso deveria ser sanado. Essa posição ideológica apresentada pelo ato perlocucionário da aluna, segundo Dijk (1998), tem como base a forma como a questão social é abordada em seu país de origem, uma vez que é notada forte presença da cultura dinamarquesa durante o ato perlocucionário. 
Na segunda charge a aluna também identifica que há um impasse social e, da mesma forma que fez na análise da primeira charge, aborda a questão de forma tranquila e equilibrada. Esse posicionamento crítico, político e social nos mostra que os temas em questão seriam bem aproveitados em qualquer tipo de tarefa em sala de aula.

\section{k. Informante 11 - PUC- Rio}

Nome: Judy Batty

Nacionalidade: Americana Data: 19/10/15
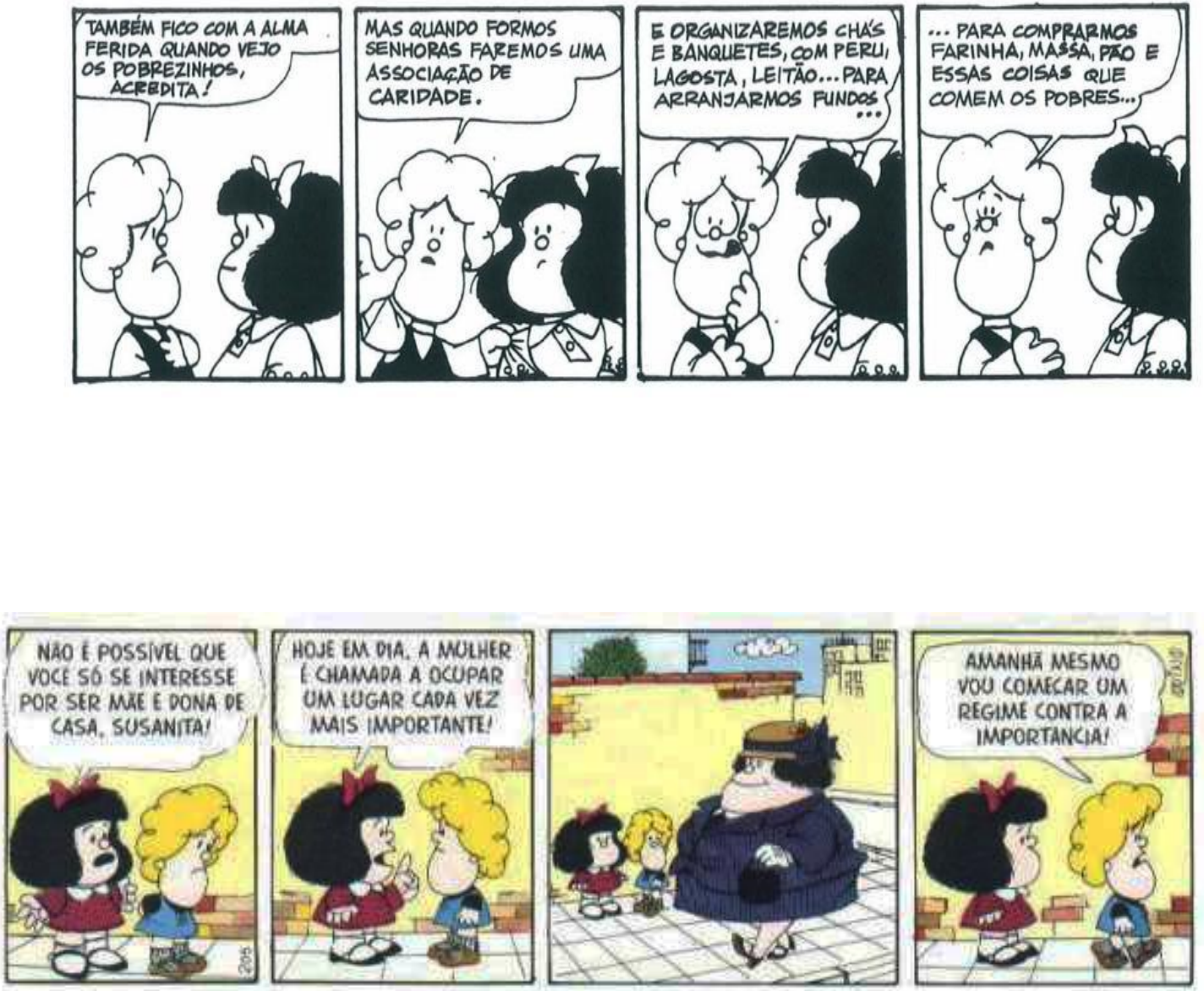

Eu acho que a primeira charge aconteceria no meu pais. Os Estados Unidos tem muitos organizações para ajudar os pobres e fazem muitos eventos para estimular as pessoas doar dinheiro. Muitas vezes o proposito do evento é 
esquecido. É irônico que tanto dinheiro é gasto em coisas para ajudar os pobres que realmente não ajuda os pobres.

Acho que também a segunda charge aconteceria nos Estados Unidos. Muitas mulheres são vistas de forma negativa por outras mulheres que se querem ser mães e não ter carreira. Alem disso, o oposto também acontece. Muitas mulheres julgam outras mulheres se trabalham afora da casa quando tenham filhos.

$\mathrm{Na}$ análise da primeira charge a aluna consegue visualizar que há preconceito social e mostra isso colocando sua opinião: essa situação é "irônica". Tendo em vista que essa situação poderia acontecer no país dela, ou seja, que o tópico para ela não é novo, e que ela não possui restrições em relação ao preconceito apresentado, esse seria um tema que funcionaria em aula. Outro ponto que vale a pena chamar à atenção é que a aluna, em ambas as interpretações, foca sua análise em como sua cultura perceberia a questão apresentada e pouco no que de fato está acontecendo nas charges. Isso é explicado, segundo Dijk (1998), pelo fato de que os Estados Unidos da América possui uma ideologia extremamente nacionalista.

Em contra partida, na análise da segunda charge, a aluna visualiza que existe um impasse social sendo abordado. Todavia, ela foca sua análise mais na discriminação de gênero do que no preconceito contra pessoas com sobre peso. Essa troca de ponto de vista foi devido, segundo Kock (2002) à discriminação de gênero ser uma questão cultural muito em voga na cultura americana entre pessoas jovens, ao menos. $\mathrm{O}$ ato perlocucionário produzido pela aluna nos mostra que o tipo de impasse abordado por ela, e não o que a charge supostamente traria, funcionaria melhor em sala de aula. 


\section{Conclusão}

Como podemos concluir, os fatores que mostraram-se mais importantes durante $\mathrm{o}$ ato perlocucionário produzido pelos alunos são a faixa etária, a nacionalidade, o grau de escolaridade e o nível de proficiência dos mesmos na língua portuguesa. Contudo, é necessário explicitar que a presente pesquisa apresenta alguns pontos que necessitariam ser desenvolvidos. Pegamos charges relacionadas somente à críticas sociais e preconceitos e, por falta de tempo e de fontes, usamos um número relativamente pequeno de informantes.

Além de melhorar esses dois fatores supracitados, é importante notar que o projeto pode ser ampliado lançando-se mão de outros gêneros textuais. 


\section{Bibliografia}

AUSTIN, J.L. Quando dizer é fazer palavras e ação. trad. Danilo Marcondes de Souza Filho. Porto Alegre: Artes Médicas, 1990

BAKTHIN, M. Os gêneros do discurso. In_. Estética da criação verbal. $3^{\circ}$ ed. trad. Maria Galvão. São Paulo: Martins Fontes, 200, pp. 279-326.

KOCH, I. Desvendando os segredos do texto. $6^{\circ}$ ed. São Paulo: Cortez editora, 2002. A coerência do textual. São Paulo: Contexto, 2006.

MARCUSCHI, L.A. Análise da conversação. São Paulo, Ática, 1986.

VAN DIJK, T. A. (1998). Ideology: A multidisciplinary approach. London: Sage Publications Ltd. 


\section{Anexo}

\section{I- Questionários:}

\section{Questionário A.}

I. Analise as seguintes charges e, depois, diga se as situações apresentadas aconteceriam em seu país/ cultura ou não.
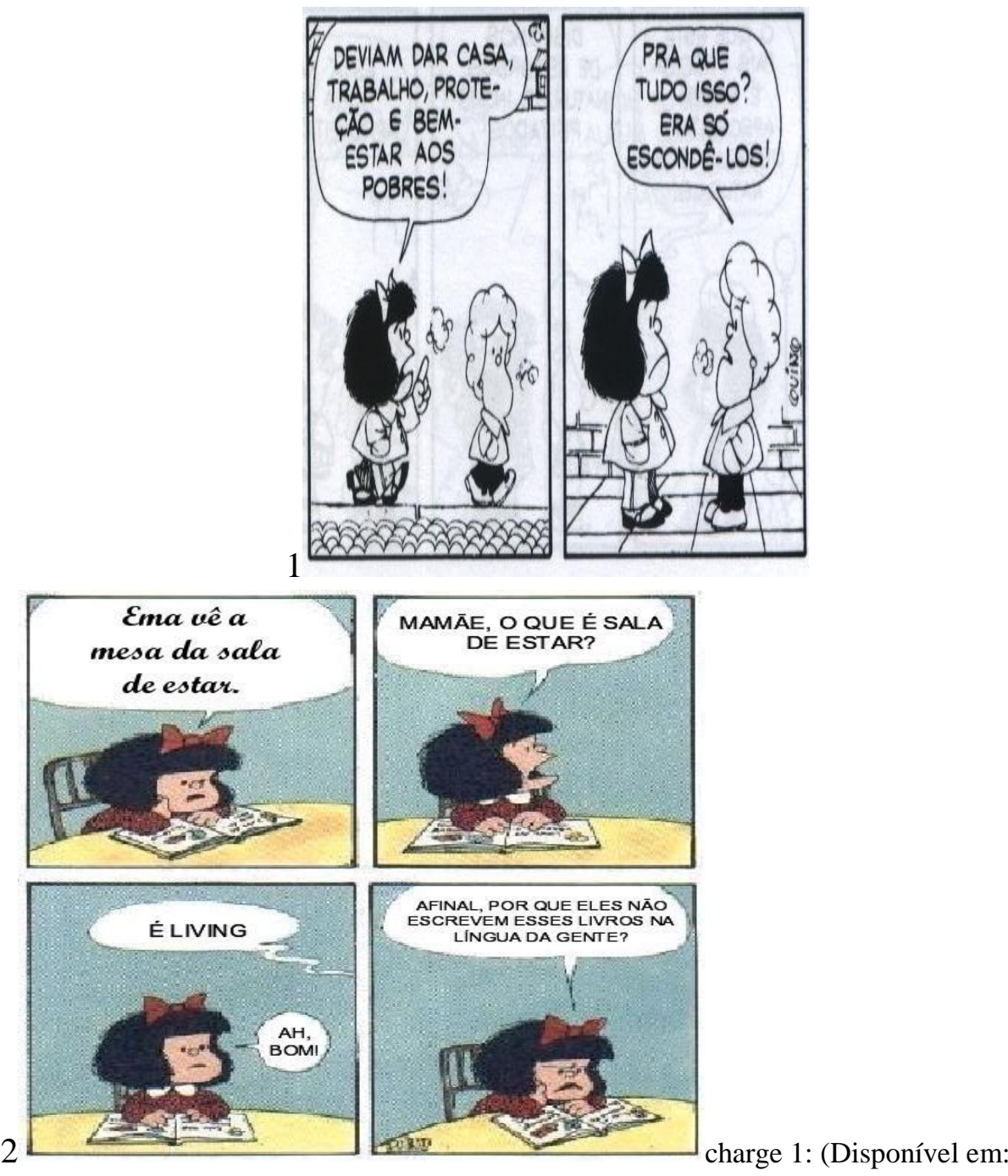

http://api.ning.com/files/jsqU1mHWkLjA7jBM-Nsi0NB-M8oYFGMjBRlda-

EcMSEakjuP4gN2HOzP1uKllb1aM7gN4bs7rfzKoawpOUe*a4BiCq8iBf8P/mafalda2.JPG. Acesso dia 27/09/2015)

Charge 2: (Disponível em: http://www.fotolog.com/sspohr/85842510/. Acesso dia 27/09/2015) 
Questionário B:

I. Analise as seguintes charges e, depois, diga se as situações apresentadas aconteceriam em seu país/ cultura ou não. 

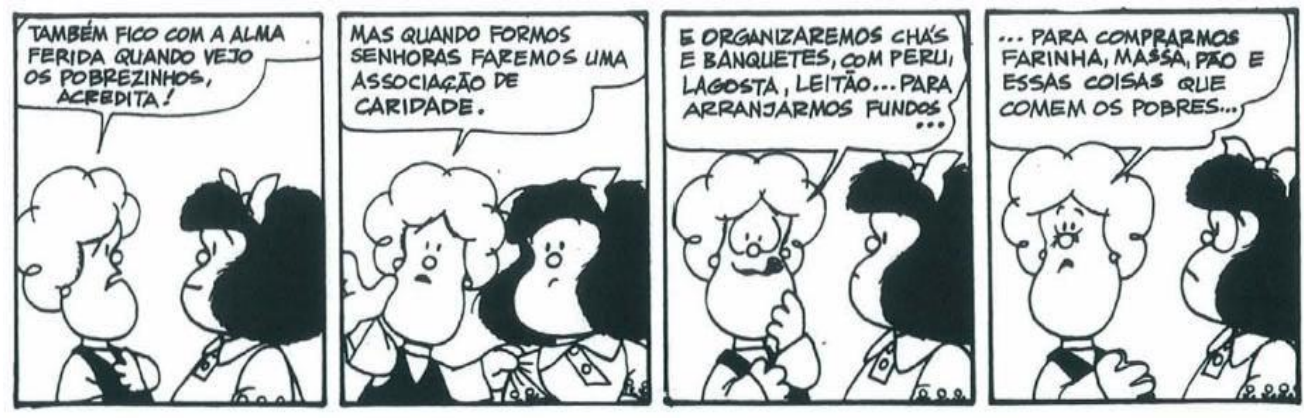

Charge 1: (Disponível em: http://lexico-familiar.blogspot.com.br/2010/12/para-os-pobres-osrestos.html . Acesso dia 27/09/2015)
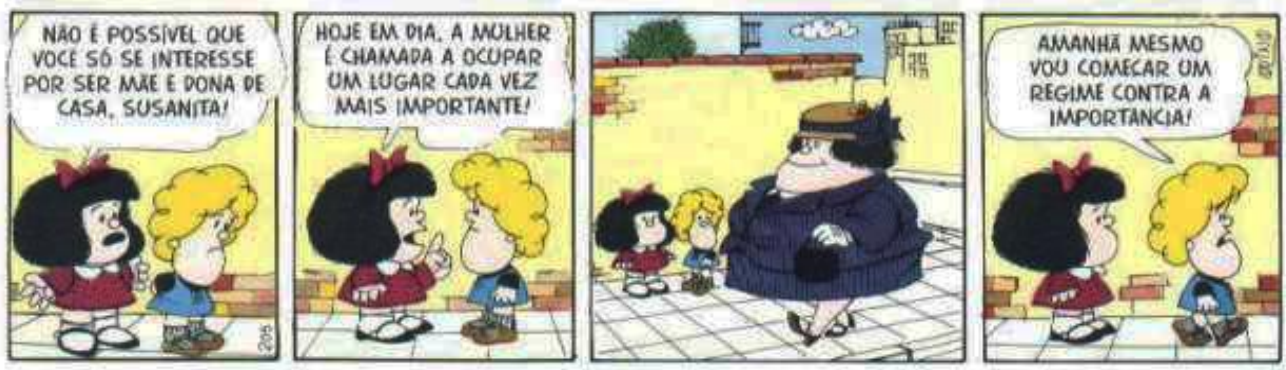

Charge 2: Disponível em: http://www.faperj.br/?id=2475.2.7 . Acesso dia 27/09/2015) 


\section{Questionário C}

I. Analise as seguintes charges e, depois, diga se as situações apresentadas aconteceriam em seu país/ cultura ou não. 

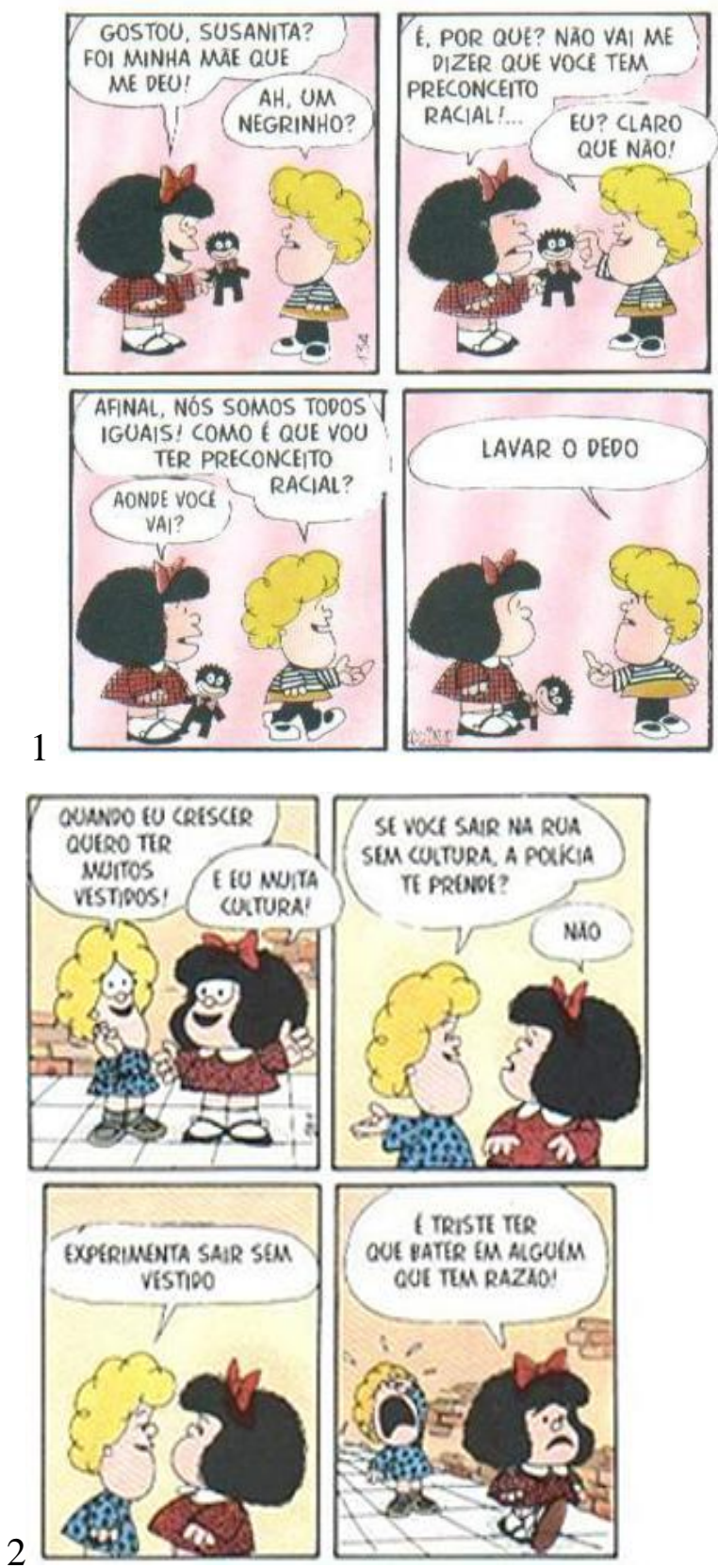

Charge 1: Disponível em: http://www.fotolog.com/mafalda_tiras/42049475/. Acesso dia 27/09/2015)

Charge 2: Disponível em: http://www.faperj.br/?id=2475.2.7 . Acesso dia 27/09/2015) 
Questionário D

I. Analise as seguintes charges e, depois, diga se as situações apresentadas aconteceriam em seu país/ cultura ou não. 

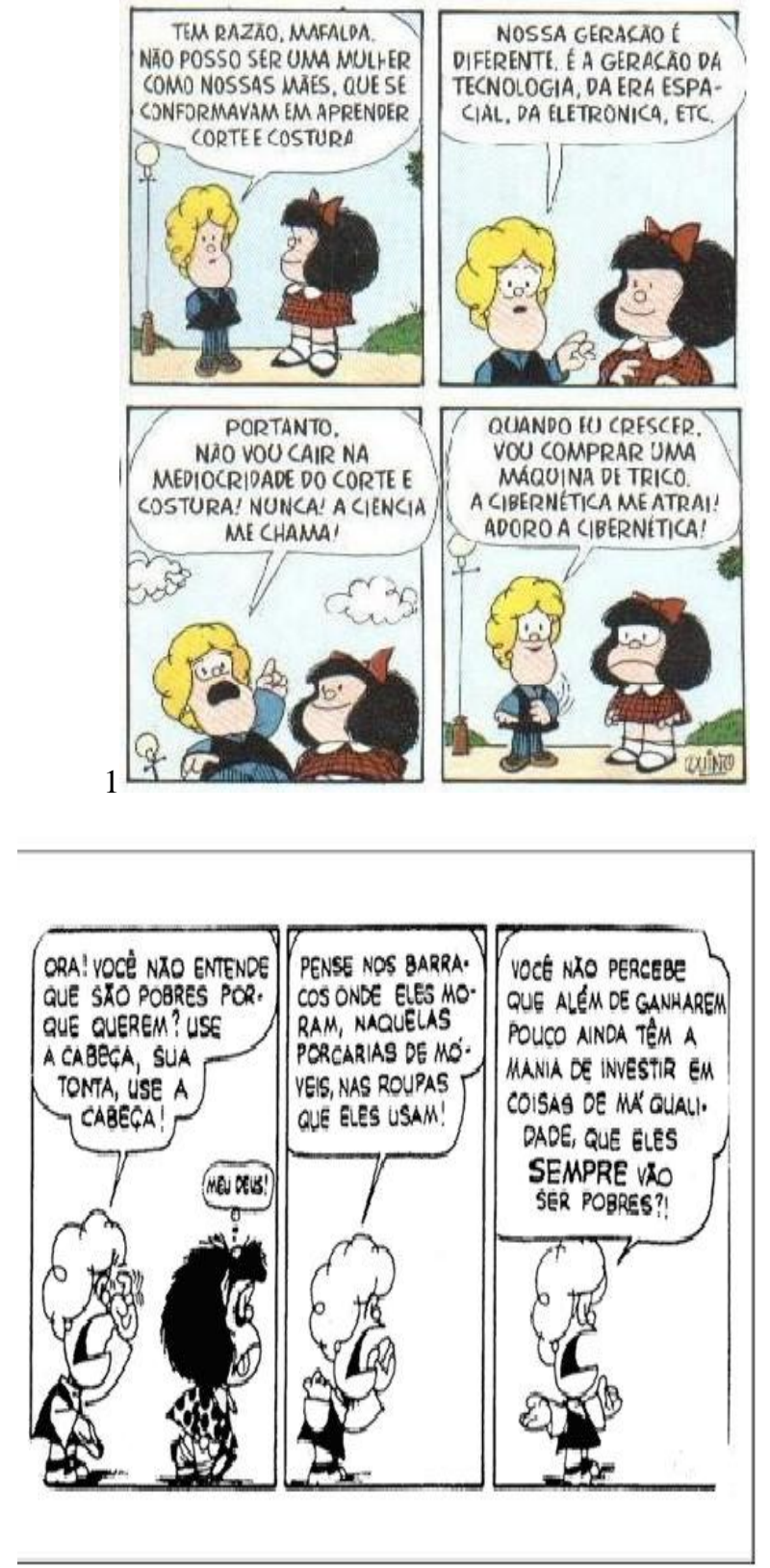

2

Charge 1: Disponível em: http://filonamidia.blogspot.com.br/. Acesso dia 27/09/2015)

Charge 2: Disponível em: http://educandonoimpossivel.blogspot.com.br/ Acesso dia 27/09/2015) 
